\title{
Church and government in Reformed
}

\author{
perspective
}

\author{
W A Dreyer (Horison) \\ Reformed Theological College \\ University of Pretoria
}

\begin{abstract}
The new political dispensation since 1994 requires the Reformed churches in South Africa to redefine their role in society and their relationship with the government. This short journey through history helps us to understand the complexity of the relationship between the Church and the government. This article focuses on the concepts formulated by the Reformers in the 16th century, presenting the view that the revolutionary and radical way in which the Reformed concepts changed society and the government is still relevant to South Africa and opens up meaningful dialogue.
\end{abstract}

\section{INTRODUCTION}

Religion, culture and politics have been closely interwoven since the earliest civilisations. In Sumerian Mesopotamia the monarchy began in 2700 BC. The "king's lists" of the Sumerians state that the monarchy had its origins from the gods. This close link between religion and politics continued in the Babylonian and Assyrian traditions (Fiore 1965:81; Caldwell 1966:38). Religious beliefs governed the full spectrum of political and economic activities in ancient times, and in some countries, such as the pharaonic religion of Egypt, the king became the god.

The Greek philosophers searched for the religious foundation of society, law and the State. By the time the Ionian settlers moved into Greece (2000 BCE) they already had a well-organised social system (Dreyer 1987:28). When the Greek philosophers came to the fore (500 BCE) they could look back on 1,500 years of culture, politics and economics and reflect on the role the gods had played in the development of Greece.

In a way similar to other early civilisations, the Old Testament recounts how the cultural and political institutions of Israel were fundamentally formed by their faith in Yahweh (Edelkoort 1957:5). Through the ages Israel's religion, culture, economy and politics have influenced one another and the king was often regarded as a priest of God (Deist 1975:35). 


\section{Church and government in Reformed perspective}

The idea that there could be any part of human society, which had nothing to do with religion, did not exist in ancient cultures, or in early Christian history, the Middle Ages or the Reformation period. Religion is the dominant factor in the politics and government of Muslim countries. It is only in the modern history of Western Europe that a secular State emerged and governments minimised the role of religion (and the Church) in government and society.

Since 1994 South Africa has been such a secular State. The South African Government is continually minimising the role of religion and the Church in public institutions, as has become clear in the recent changes to the school curriculum. This requires the Church to redefine its role in South Africa.

Historical examples may help the Church to understand the present situation. The view presented in this article is that the revolutionary and radical political concepts formulated by the Reformers in the 16th century are still relevant and applicable to South Africa.

\section{REFORMED UNDERSTANDING OF THE BIBLE}

The Reformers of the 16th century based their theology, and their understanding of politics, on their interpretation of the Scriptures. They understood two things:

- Firstly, the relationship between the Church and the government is one of great distance (Van Niftrik 1950:22). Ecclesia does not mean "called from the world" (Louw \& Nida 1988:126), but instead indicates a society in contradistinction to other societies, such as one city which is distinguished from another city. When the early Church called itself ecclesia, it distinguished itself from other ecclesiae. The first Christians knew that the Kingdom, of which they were part, was different from earthly kingdoms. They knew the answer Jesus gave to Pontius Pilate: My kingdom is not of this world ...

The earliest Christians knew that this world was transient, and they prayed: Maranatha! They expected martyrdom instead of political power; poverty instead of riches. They even went as far as viewing the government and kings as the beast and antichrist (Revelations 13). In the letter to Diognetos (2nd/3rd century) we read: "For the distinction between Christians and other men, is neither in country nor language nor customs ... following the local customs ... They dwell in their own fatherlands, but as if sojourners in them ... they suffer all things as strangers ..." (Lake, K trans Apostolic Fathers II:359). 
- Secondly, the gospel was of immense political importance (Van Niftrik 1950:25). Why did the Roman Empire, which allowed different gods to be worshipped, persecute the Christians so harshly? New gods were constantly being given a place in the Roman pantheon. If Christ had been such a god, just one among the others, there would have been no problems for the Christians. But the moment the Christians proclaimed Christ as the One to whom all the power and glory in heaven and on earth belonged (Mt 28), it had political consequences. Christ is the Son of God, and not Caesar. Christ is the only Kurios; whereas on the throne in Rome there sits a kurios. Jesus is the King of kings and the Lord of lords (Rv 9:16). God reigns over heaven and earth. The moment this is professed, the gospel becomes political.

The Reformers had immense respect for the government, mainly based on their understanding of Romans 13. This is the reason a Reformer like John Calvin was opposed to any form of rebellion against a legal government and advised his followers to emigrate as an alternative to violent rebellion. The result was a mass emigration by French Protestants.

\section{MARTIN LUTHER}

The first important Reformer was Martin Luther. Luther had a great appreciation for the thoughts of Augustine, and used them extensively. Aurelius Augustine lived from 354-430 CE. He is called Doctor Charitatis, because he understood politics in terms of God's love (Versfeld 1987:118). $\mathrm{He}$, more than anyone else, was responsible for the confluence of the classical culture and Christian faith. In this way he contributed to the development of Western civilisation. Augustine distinguished clearly between the eschatological civitas Dei and the civitas terrena, that is the eternal kingdom of God and the earthly kingdoms that rise and fall. These two kingdoms are at war. The earthly kingdoms are the civitas diaboli. Augustine teaches that man can only be a citizen of the one or the other kingdom.

The civitas terrena, according to Augustine, only has a right to exist if governments govern their people in a loving and just way. Without love and justice, governments become a magnum latrocinium - a band of robbers (Mans 1962:95; De Civitate Dei IV.4). For Augustine justice is the essence of the State, and the essence of justice is the amor Dei.

Luther used the Augustinian distinction between the spiritual and earthly kingdoms as his conceptual matrix, although he had a greater appreciation for government than Augustine did. In his exposition, he does not try to distinguish between the Church and the State, but rather to describe the 


\section{Church and government in Reformed perspective}

dualistic acts of God in terms of His creation, which had fallen in sin (Kooiman 1957:1107).

Because Luther places great importance on the acts of God, he prefers to speak of two regimes than two kingdoms. He explains that God governs in two ways over His creation: He governs firstly and directly through His spiritual regime (the preaching of the Word and the gospel of grace). This spiritual governance applies to all the children of Adam who come to the true faith in Christ Jesus. He who hears the gospel and believes is a new creation and does not need the earthly government (Luther [1523] 1955:146).

Secondly and indirectly, God governs through the earthly regime, that is the earthly government. God appoints governments to protect His creation from chaotic and diabolical powers. This governance takes place not through the gospel of grace, but also through the law. The law and the government are meant primarily for the children of Adam who do not know or serve God (Luther [1523] 1955:147).

This concept of the two regimes should be understood against the backdrop of Luther's theocentric theology and his understanding of creation. Man is subject to both regimes, because God instituted both. The spiritual regime is not only inner spirituality, but also influences society as a whole. Ein Christ muss zwei Personen auf Erden tragen, Christperson und Weltpersona Christian must live in this world as a Christian. A Christian lives in this world in the presence of God (coram Deo), under the regime of the Word as a justified sinner (simul iustus ac peccator). In this world the Christian lives in the presence of people (coram hominibus) as a father, mother, son, daughter, king, judge, priest or servant. As such a Christian has a double calling: he is called by the gospel to faith, but simultaneously called to fulfil his task in this world.

Luther understood that when God created the world, He did not abandon the world. Nevertheless, this world is not the final reality. It can never become paradise. For a Christian, this world remains a temporary dwelling. This world is the place where the gospel must be preached, but Luther did not envisage a christening of the government and culture. Culture will not be sanctified by grace (Kooiman 1957:1108). The kingdom of God is not visible in Christian or public structures. The polarity between the two kingdoms and two regimes may never be ignored.

\section{JOHN CALVIN}

At the time that John Calvin came to Geneva in 1536, the council of the citystate (canton) made all the political and ecclesiastical decisions. The pastors could voice an opinion, but had no power to make independent decisions 
(Dreyer 1995:15). This situation was unacceptable to Calvin. When Calvin resisted the government's powers in the Church, he and other pastors were banned from Geneva. After his return in 1541 he continued to establish a Church Order in which the elders of the congregation could take decisions as well (Pont 1986:31; Buys 1980:100-105).

The basis of Calvin's understanding of the relationship between the Church and the government was his belief that worldly and ecclesiastical governance differ fundamentally. Because of this insight, he tried to establish a greater separation between Church and the government. To put this relationship into words, Calvin used the concept of a covenant.

It is clear in the political history of Western Europe that Calvin's understanding of the covenant had strong influence (Torrance 1990:1). His understanding of the covenant filled the gap left when the feudal system came to an end. It also countered the emergence of an extreme form of the ius majestatis, or divine right of the king (Dreyer 1995:17).

The basic problem of $16^{\text {th }}$-century politics was the limitation of the powers of the government. Calvin used the concept of the covenant to describe the rights and duties of the people on the one hand, and the rights and duties of the government on the other (Torrance 1990:9). There are many examples of such covenants, the best-known are the "Covenants" in Scotland. Torrance states (about Calvin's concept of the covenant):

Here was a conceptual matrix (with its notions of natural law,
contract, ius naturale, ius civile, ius gentium, sovereignty, etc. so
familiar in Western Europe), within which Calvin's theology was
readily reinterpreted as federal theology and went to the grassroots
of nations and Churches struggling for justice and liberty, seeking
always-biblical justification and precedent for their theology and
practice...

(Torrance 1990:11)

Another theme in Calvin's understanding of the relationship between the Church and the government is his concept of order (Milner 1970). He had a certain understanding of order (which is found even in antiquity in the pharaonic religion). According to Milner, Calvin distinguished three instances where God created order: the cosmos, mankind and in society. When man fell in sin, the cosmos, mankind and society fell into disorder. To return these three to a state of order, God created the Church and Governments. It is the calling of the government and the Church to curb sinful disorder in society through secular and spiritual government. As such, the Church and the government have the same aim - people must live in an orderly society, 


\section{Church and government in Reformed perspective}

loving God and their neighbours. Secular government is accomplished by law and the judicial system; spiritual government by the Word of God.

Like everyone else in the Middle Ages and in the 16th century, Calvin understood society in terms of a theocracy. God reigns over creation, including man and society. Against this background, Calvin proposes that a government is responsible for society's adherence to the Ten Commandments. It follows therefore that the government itself must abide by the Ten Commandments. This is radically opposed to the notion of the ius majestatis where the king is the source of the law and is elevated by divine right above the law. In France and Italy the king had an almost divine power over life and death. The theocratic ideas of Calvin laid the foundation of what we understand today as the rule of law, where the government is bound by law and must subject itself to all the laws promulgated by parliament. In the Netherlands, Calvin's thoughts led to the creation of a rechtstaat, in which the highest authority was vested in the laws promulgated by parliament (Dreyer 1995:23).

Calvin placed great emphases on humane (humanitas) and just (iustitia) governance (Inst IV.20.3/4/6/20/29/30/31). He stressed this mainly in relation to the way judges administered the law. In his opinion, judges were the most important people in society. This notion is understandable, as he was a jurist himself. He contributed greatly to the high regard people have for a fair judicial system.

\section{BELGIC CONFESSION}

One of the most influential Calvinistic documents is the Belgic Confession. It was compiled by Guido de Brès (1522-1567), a pastor of the Reformed Church who had studied with Calvin in Geneva. The French Confession, which for the greatest part was the work of Calvin and accepted by the French Reformed synod in Paris in 1559, preceded the Belgic Confession which De Brès wrote in 1561. In 1563 the Dutch Reformed Church probably discussed it at a secret meeting. The Synod of Antwerp revised it in 1565 and accepted it as a confession of the Church (Bosman et al 1987:1-7).

When studying the text, it is clear that the Confession was an apology. In the introduction De Brès addresses the king and pleads for his mercy towards the reformers. De Brès, like Calvin, uses two principles in his apology to the king: the Word of God and the ius naturalem. He emphasises that the hidden witness of our consciences and also the Word of God teach us that rebellion against the king is a terrible sin.

De Brès used Romans 13 in his exposition. Governments are instituted by God, and are part of God's order (Calvin) in this world. Everyone who does 
not accept the authority of a legal government, not only rejects a temporal government but also rejects God's authority. In this way he tried to give Philips II the assurance that the Reformation was not aimed against the king or at undermining royal authority. All the Reformers wanted was the freedom to serve God in the way that they understood the Word of God.

Article 36 of the Belgic Confession formulates the theocratic structure of society. This may be summed up as follows:

- God instituted governments to maintain order in society.

- $\quad$ Governments should punish lawless people and protect law-abiding citizens.

- Governments should not only ensure the development of the State, but also the protection of the Church.

- $\quad$ Everyone must accept the authority of the government.

- $\quad$ Order in society is necessary for peace and a God-fearing life.

- The Anabaptist opposition to the temporal power of the government is rejected.

- The government's power is limited by its own adherence to the Word of God.

- $\quad$ Everyone must pray for the government.

- $\quad$ Everyone has to pay tax.

It is interesting that the relationship with the government is part of this Confession, indicating how important it was for the Reformers to take the Word of God seriously. If the Bible teaches respect for the government, that is the way a Christian should live. But the government should govern according to Biblical principles, namely with justice, love and humanity. In this way a theocracy, a government instituted by God and obedient to God, would come into being (Koopmans 1939:244-279).

\section{VINDICIAE CONTRA TYRANNOS}

One of the most influential Reformation documents on the relationship between the Church and the State is the Vidiciae contra tyrannos. This document was a reworking of Theodore Beza's De iure magistratuum in subitos, et officia subitorum erga magistratus, in short De iure magistratuum. Beza's works were reprinted 88 times and his influence is clear in the extensive use of his ideas in the English, Scottish, French, Dutch and Hungarian publications of the time. His ideas influenced documents such as the Dutch Plakkaat van Verlatinge, the Vindiciae contra tyrannos, the Edict of Nantes, the Scottish Covenants, the French Pact du Peuple présenté au 


\section{Church and government in Reformed perspective}

Parlement of 1649 and the American Declaration of Independence (Van Schelven 1956:11). The Vindiciae contra tyrannos is not only a reworking of Beza's De iure magistratuum, but also of Hotman's Franco Gallica published in 1573 (Murray 1962:37). The Vindiciae is the single most important document in the political history of the Netherlands (De Visser 1926:89; Kuyper 937:194).

Beza was Calvin's successor in Geneva. He consistently opposed the absolute powers of the government and the king. The government regarded the De iure magistratuum, and other Calvinist literature, as revolutionary (Sabine 1951:322).

The revolutionary aspects of Beza's thinking can only be understood against the backdrop of the massacre of 20000 French Protestants in Paris in 1572. Beza wrote about citizens' right to resist the unlawful actions of the government as well as the relationship of the government to its people. At the heart of all this was Beza's conviction that no government had absolute power, at a time when the French king had absolute power (Van Schelven 1956:4; Sabine 1951:319).

The De iure magistratuum was a critique on the naturalist, humanistic, empiricist and pragmatist vision of the government. Beza formulated a Christian-ethical vision of the State. His democratic vision is revealed in his formulation that the people do not exist for the sake of the king; but rather the king exists for the sake of the people (Beza [1574] 1956:30). This principle had a fundamental influence on the development of modern democracies.

The Vindiciae contra tyrannos (Brutus 1579) was published in 1579 in Edinburgh under the pseudonym of Stephanus Junius Brutus. It is generally accepted that the author was Du Plessis Mornay. His reworking of the De iure magistratuum made Beza's ideas more understandable and readable, and had an extensive influence. Few people realised that the work was not completely original (Van Schelven 1956:9-11). Du Plessis Mornay was a French Protestant who was subjected to the extreme measures that the French king took to curb the growing Protestant movement.

In the Vindiciae the rights of peoples and groups within the kingdom are described as a God-given right. These rights of the people are entrenched in a covenant. This means that several States and provinces could live together in one kingdom without fear of being victimised by the king or other States. This principle became known as pluralism. Pluralism has its origins in the Vindiciae and has become one of the most important principles in Calvinist political theory (Brutus 1972:90-93). Pluralism was the principle that made the Union of Utrecht possible, and was the basis of the Dutch State until Napoleon Bonaparte conquered the Netherlands (Murray 1962:17). 
Another important principle formulated in the Vindiciae is that the law should be maintained as the highest authority in the kingdom and States. The powers of the government are limited by civil law and the Ten Commandments (Brutus 1972:73). The government as well as the people is expected to abide by the law. In this we find the earliest formulation of the rule of law.

The Vindiciae also points out that the government should not only govern to the betterment of society, but should also protect the Church. Murray summarises this in the following statement:

Its principles are clear. The magistrates must serve the Church and must protect her. But more: their duty is actively to promote the spread of the interests and the teachings of the Church. These points mark one of the main distinctions in the cleavage which occurs in subsequent political theories. Natural Law theories of the naturalist type assert the sovereignty of the State and so place the Church under the State; or at best make one religious denomination a national Church. The old tradition continues to maintain the principle that the secular institutions of the State have their duties to the Church. Its principle of the spiritual universality of the Church with its earthly pluriformity enables it to stand for the principle of religious rights, and not merely plead for toleration. To this extent it adapts itself to new conditions. It maintains the principle of corporative autonomy of the Church, and of the duty of the secular authorities to maintain, defend and extend the Christian religion.

(Murray 1962:25)

\section{CONCLUSION}

It is clear that Calvinists always had a lively interest in politics, because they were convinced that the Christian faith concerns not only heaven and spiritual matters, but also this world and our daily existence (Neill 1967:411). This has been the case in South African history too. Lately the Reformed churches in South Africa have been at sixes and sevens on what, and how, they should witness to the government and society. Many of the principles widely used in South Africa clearly have their origins in Calvinist political theory. It was extremely interesting to note in the previous election that the African National Congress, as the ruling party with a revolutionary background, often used the phrase "a people's contract" in their election campaign, without realising that this phrase was coined in sixteenth-century Calvinist political theory. This opens the possibility of meaningful dialogue between the Reformed churches and the government. 


\section{Church and government in Reformed perspective}

In dialogue with government, the Church must remember that it exists in the time between the advent of Christ and His return; that in Christ the kingdom of God had come very close; that the Christian is first and foremost a citizen (politeuma - Phil 3:20) of God's kingdom. At the same time the Church realises that it is not in heaven, but on earth. The Church also knows that peace, freedom and human dignity, which governments should ensure, will always be provisional and partial. In spite of the limitations of human endeavour and the creation of an ideal society, the Church cannot ignore politics, culture, people's aspirations and economic advancement. The Church does not belong to the world, but is called to step into the world with the Word of God, to witness that Jesus Christ is the risen Lord who governs His Church through His Word and Spirit; who is Lord of all creation.

How can we view the reciprocal relation between, and responsibilities of the Church and the government?

Firstly, these can be viewed from a juridical perspective. The Church and the government are both bound by the laws passed by parliament. If laws are passed which the Church deems to be unjust, or against the will of God, that view must be witnessed and communicated. The Church is not obedient to the government, but respects the law. This is a matter of principle (Article 36 Belgic Confession/Romans 13). The Church can never be forced to respect the law; such respect is a matter of Christian conscience. For this reason Christians should pay tax, refrain from crime and be committed to upholding law and order.

Secondly, the Church has a prophetic calling with regard to the Government. This implies not only a clear witness against injustice in society, but also a clear witness that true peace, freedom, justice and reconciliation can only be found in and through Jesus Christ. The best service the Church can give to the government is to preach the gospel of Jesus Christ (Van Niftrik 1950:32).

Thirdly, the Church has a priestly relationship with the government. It is the duty of the Church to pray for the government. According to Luther, the Christian also has a priestly office and calling to witness in society and to the government that Jesus Christ is the risen Lord.

Fourthly, the Church still has a responsibility to govern. With freedom of conscience (Heidelberg Catechism 12/32) the Church has to fight evil and sin in society. The Church has the sword of the Spirit, the Word of God that must be used to eradicate evil. The Church governs by the Word, under guidance of the Holy Spirit. Christ is King of Church and Creation, He is King of kings and Lord of lords - and He must be proclaimed as such. By making the Ten Commandments applicable to all Christians, they are governed by the Word 
and Spirit and at the same time become law-abiding citizens in society (Van Ruler 1945). The highest authority for the Church is Jesus Christ. The Church acknowledges the authority of the government to govern the country, but the Church is governed by its King, Jesus Christ through His Word and Spirit. Accordingly, the government has only limited power.

In the fifth place, the Church and the government must work for a just, humane and free society. This implies a fair and effective judicial system. In the sixth place, the Church and the government both respect the law and the rule of law. The government should place the highest priority on its campaign against corruption, against public figures and officials who think that they are above the law.

The government and Church will have to respect fundamental human rights and the vested rights of communities to their cultural heritage. Pluralism is still relevant. The acceptance of diversity and the protection of minorities and their rights are possibly among the greatest achievements of civil society.

In the eighth place, the maintenance of order is still important.

Disruptive and destructive civil action should be avoided, and the role and importance of different entities in society acknowledged.

It is my opinion that the Reformed churches in South Africa should use Reformed political concepts in structuring their relationship with the government. These concepts are still relevant - perhaps even revolutionary in some ways. By listening to the Scripture and the Reformed fathers, a way could be found to hold constructive dialogue with the government and improve a just and free society.

\section{Works consulted}

Allen, J W 1961. A history of political thought in the sixteenth century. London: Methuen.

Augustine, A 427. De civitate Dei, in The basic writings of St Augustine. New York: Random House.

Baird, H M 1970. Theodore Beza. New York: Burt Franklin.

Bakhuizen v d Brink, J N 1940. De Nederlandsche Belijdenisschriften Vergelijkende Teksten. Amsterdam: Uitgeversmaatschappij Holland.

Bakhuizen v d Brink, J N 1980. Handboek der Kerkgeschiedenis, deel 3. Leeuwarden: De Tille BV.

Barth, K 1954. Against the stream. London: Mowbrays.

Beza, T [1574] 1956. De iure magistratuum in subitos, et officio subitorum erga magistratus, tr by H L Gonin, in A H Murray (eds). Cape Town: HAUM.

Bodlaender, M L 1959. Politeia: Grote mannen over staat en maatschappij. Amsterdam: Elsevier.

Bosman, H L (ed) 1987. Die Nederlandse Geloofsbelydenis: Ontstaan, Skrifgebruik en Gebruik. Pretoria: University of South Africa. 


\section{Church and government in Reformed perspective}

Botha, S J 1996. Die corpus christianum gedurende die Middeleeue. Lectures, University of Pretoria.

Brutus, J [1579] 1972. Vindiciae contra tyranno, translation by Laski, H J 1972. New York: Burt Franklin.

Buys, F 1980. Die verhouding tussen Kerk en staat by Calvyn in Kerkhistoriese perspektief. Studiae historiae ecclesiasticae VI.

Caldwell, E C et al 1966. The ancient world, 3rd edition. Hinsdale: Dryden Press.

Cavyn, J [1559] 1949. Institutio christianae religionis, translation by A Sizoo. 2nd edition. Delft: Naamloze Vennootschap W D Meinema.

De Visser, J Th 1926. Kerk en staat deel 2. Leiden: A W Sijthoff's Uitgeversmaatschappij.

Deist, F 1975. Die noodlottige band: Die verhouding tussen kerk en staat in OudIsrael. Kaapstad: Tafelberg.

Dreyer, P S 1987. Die voor-Platonise staatsbeskouings, in A M Faure (ed), Die Westerse politieke tradisie. 2e uitgawe. Pretoria: Academica.

Dreyer, W A 1995. Kerk, volk en owerheid: 'n Hervormde perspektief. PhD dissertation, University of Pretoria.

Faure, A M (ed) 1987. Die Westerse politieke tradisie. Pretoria: Academica Fiore, S 1965. Voices from the clay. Norman: University of Oklahoma Press.

Haitjema, Th L 1957. Calvijn en de Calvinisme, in J Waterink (ed), Cultuurgeschiedenis van het Christendom, 1132-1175. Amsterdam: Elsevier.

Haitjema, Th L 1964. De nieuwere geschiedenis van Neerlands Kerk der Hervorming. 's-Gravenhage: Boekencentrum n v.

Kooiman, W J 1957. Luther, in J Waterink (ed), Cultuurgeschiedenis van het Christendom, 1104-1131. Amsterdam: Elsevier.

Koopmans, J 1939. De Nederlandse Geloofsbelijdenis. Amsterdam:

Uitgeversmaatschappij Holland.

Kuyper, A 1937. Briefwisseling van mnr Groen van Pinsterer met dr A Kuyper 18641870. Kampen: Goslinga.

Lake, K trans 1965. The Epistle to Diognetus, in The Apostolic Fathers, vol 2, 348379. London: William Heineman.

Louw, J P (ed) 1988. Greek-English lexicon of the New Testament. Goodwood: National Bookprinters.

Luther, M [1523] 1955. Von Weltliche Obrigkeit, die neue Auflage, in Steck, K G (Hrsg) Luther, 141-170. Frankfurt: Fischer Bucherei.

Mans, C J 1962. Die owerheid in die Nuwe Testament en by die Reformatore. HTS 18, 90-115.

McNeill, J T 1967. The history and character of Calvinism. New York: Oxford University Press.

Milner, B C 1970. Calvin's doctrine of the Church. Leiden: Brill.

Murray, A H (ed) 1956. Theodore Beza. Cape Town: HAUM.

Murray, A H 1962. The political philosophy of $J$ A de Mist. Cape Town: HAUM.

Murray, A H 1987. Inleiding, in A M Faure (red), Die Westerse politieke tradisie. Pretoria: Academica.

Sabine, G H 1951. A history of political theory. London: George G Harrap.

Saggs, H W F 1962. The greatness that was Babylon. London: Sidgwick and Johnson. 
Torrance, J B 1990. The concept of federal theology: Was Calvin a federal theologian? Lectures at the Calvin Congress, Grand Rapids, MI.

Van Niftrik, G C 1950. Geloof en politiek. Kerk en Theologie 1(1).

Van Ruler, A A 1945. Religie en politiek. NijKerk: 's-Gravenhage.

Van Schelven, A A 1956. Introduction, in A A Murray (ed), Theodore Beza. Cape Town: HAUM.

Versfeld, M 1987. Aurelius Augustinus, in A M Faure (red), Die Westerse politieke tradisie. Pretoria: Academica.

Von Hippel, E 1958. Geschichte der Staatsphilosophie. Meisenheim am Glan: Verlag Anton Hain. 